\title{
Иисус Христос в устойчивых сравнениях христиан
}

\author{
И. В. КУЗНЕЦОВА \\ Кафедра педагогики и методики начального образования, Чувашский государственный \\ педагогический университет, ул. К. Маркса, д. 38, RU-428000 Чебоксары \\ E-mail: irinak47@yandex.ru
}

(Received: 12 December 2014; accepted: 27 March 2015)

\begin{abstract}
This paper makes a comparative analysis of fixed similes with the component Jesus Christ and its synonyms, their representation in dictionaries, and their usage by native speakers. As a result, the author reveals biblical structural semantic universals as well as set comparisons with national peculiarities.
\end{abstract}

Keywords: biblical phraseology, phraseography, dynamic processes, biblical characters, Jesus Christ, etymology

В фонде библейской фразеологии ${ }^{1}$ много единиц со структурой сравнения, которое в языке выражается морфологически и синтаксически - среди последних немало конструкций с компаративным союзом. Рассмотрим те из них, в которых образом для сравнения выступает главный персонаж новозаветных канонических и апокрифических сказаний - Иисус Христос. Хотя в Священном Писании ничего не говорится о внешности галилейского пророка, а в произведениях искусства он запечатлен и безбородым (подробнее см. МНМ 1: 501-503, Косидовский 1990: 386), в народных сравнениях Христос предстает заросшим, с бородой и с усами: рус. заросший как Иисус (БИРИХ-МОКИЕНКО-СТЕПАНОВА 2005: 270); обросший бородкой как Христос (Кузнецов А. Бабий яр, 1965-1970)*; оброс как Христос в пустыне ${ }^{3}$ (Конецкий В. Начало конца комедии, 1978)*; укр. борідка як в Icyca, a очі як у бica (ДоБРОльОЖА 2003: 65); чеш. být (chodit) [bradatý, fousatý] jako Kristus; нем. bärtig wie ein Jezus sein (SČF 1983: 175).

В компаративных фразеологизмах высока оценка моральных качеств Иисуса: рус. как [Иисус] Христос 'о тихом, скромном, чистом, непорочном

${ }^{1}$ К библейским фразеологизмам мы относим единицы, «деривационно связанные с Ветхим и Новым Заветом или апокрифическими (неканоническими) христианскими текстами» (ІвченКо 1999: 190).

2 Примеры со знаком «звездочка» (*) взяты из НКРЯ.

3 Заметим, что обстоятельственный компонент активен в русских компаративизмах (видимо, благодаря известной картине Н. Крамского «Христос в пустыне») и сочетается с разными основаниями сравнения. В текстах чаще встречается фразеологизм искушать как Христа в пустыне 'подвергать различным соблазнам': «Федора Михайловича искушали друзья, и, заметьте, из лучших побуждений. Как Христа в пустыне» (Гордеевы Е. и В. Не все мы умрем, 2002)*; «В самой же „Меланхолии“ узнается образ искушаемого человека, подобного Христу в пустыне» (Шевченко В. Демон науки: «Меланхолия». // «Знание - сила», 2003)*; слвц. «...је vystavený mnohým pokušeniam (ako Ježišso na púšti) a je obdivuhodné, ako pokušitel'...» (SNK). 
человеке' (Огольцев 2001: 736); как Христос 'о боголюбивом, праведном, чистом душой человеке' (Мокиенко-Никитина 2008: 726); хорв. pravedan kao (ko) Isukrst (MeNAC 2003: 365). В текстах сопоставление с Христом может реализовывать и другие значения. Семантику 'человек, являющийся непререкаемым авторитетом для кого-либо' мы видим в строках: «- Для меня и для Галы товарищ Сталин... - Как Иисус Христос, - сказала Гала. - Слово коммуниста, - продолжил Валентин Юрьевич, - мы эту реликвию сохраним до тех самых пор, пока она гордо не станет на свое законное место» (Войнович В. Монументальная пропаганда, 2000)*; значение 'человек с единством черт характера, лишенный раздвоенности', - в строках: «Они думают, что я Сталин. Цельный, как Христос» (Джин Н. Учитель, 1980-1998)*. Абсолютную честность Иисуса подчеркивают компаративизмы: рус. как (словно, будто) [Иисус] Христос честный (чистый, непорочный) (ОГОЛЬЦЕв 2001: 736); честный как Иисус [Христос]; укр. чесний як Христос (ЛЕвченко 2007: 374); лемк. чесный як Христос (ВАРХОЛ-ІВченко 1990: 139). Для семантизации фразеологизма важен и контекст, который влияет на стилистическую окраску и может менять позитивные ассоциации на противоположные: «- Видите ли, - издевался старик, - честнейшему, как сам Иисус Христос, Сережке стыдно характеру у товарища подзанять» (Зорин Д. И. Русская земля, 1966). Устойчивые сравнения отмечают и умение Иисуса прощать людям их грехи (Лк 7: 37-49), что обыгрывается в русской поэзии: «В дни скорби демон испытанья / Его с пути не совратит, / И, как Христос, свои страданья / Он палачам своим nростит!» (Сатин Н. М. Христианин, 1841)*; «Ни в теле, ни в душе нет больше прежних сил; / С весной цветущею я вновь не молодею / И только рифмою по-прежнему владею, / Сонетом же одним едва ль Вам буду мил... / Простите ж, как Христос, распятому злодею!» (Кондратьев А. А. «Цветут глицинии. Волной бледно-лиловой...», 1918)*. Сравнения типа верить [в кого, во что] как в (во) Христа или терпеть как Иисус [Христос] частотны в православной и католической риторике, но редки в художественной литературе и публицистике: рус. «Превратившийся в благополучного, примирившегося с собой, миром и системой буржуа Джон Леннон перестал быть Ленноном, и веривший в него, как в Христа, фанат не простил предательства: Марк Чепмен, долгие годы молившийся на «битла» неудачник, пришел к его дому с пистолетом» (Филиппов А. Реконструкция любви. Леннон и Оно: факты на месте, тайна отсутствует. // «Известия», 31.10.2001)*; «Крупные и мелкие дьяволы часто искушали его, пытаясь посеять сомнения, но он терпел, как Иисус Христос, в которого он не верил» (Войнович В. Монументальная пропаганда, 2000)*; слвц. trpím ako Kristus na krízi (SNK).

Один из мотивов Библии - столкновения Иисуса с иудейскими ортодоксами, вызванные тем, что он «постоянно нарушает формальные табу иудаистической религиозной практики» (МНM 1: 493), отражают ушедшие в пассив восточнославянские фразеобиблеизмы с антонимичными планами выражения и содержания: рус. виноват как Иисус Христос перед жидами (Михельсон 1: 47); укр. виноватий як Христос перед жидами (Номис 1993: 205). Без 
краткого экскурса в теологию и осознания различной оценки личности Иисуса в иудаизме и христианстве трудно понять противопоставление иудеев Христу в этих оборотах. С позиций иудаизма они вполне закономерны, ибо евреи отвернулись от Иисуса, не соблюдающего Тору (Закон). Кроме того, иудаизм не признает Иисуса Христом, т. е. Мессией (Мєббі $\alpha$ - греческая калька с др.-евр. māšlijah 'помазанник'). На уровне же христианского мировоззрения, где Иисус приравнивается к Богу, является богочеловеком, совместившим в себе божественное и человеческое начала, воплотившимся Богом-сыном, Мессией, происходит трансформация семантики компаративизма и еврей превращается в антагониста Бога (= Христа) на земле (об этом см. КузНЕцОВА 1995: 195-196). Значение фразеологизма формируется двуступенчато: противопоставлены лексемы в компаративной части, антонимичны планы содержания и выражения. Существующее на уровне бытового сознания противопоставление 'иудей' - 'Христос' не отражает того факта, что «христианство основано на еврейской Библии и следует учению Христа, который был евреем» (Бохеньский 1993: 22), и основано на парадоксах теологии. Оборот устарел в силу своей книжности, «непрозрачности» для современного носителя языка и, вероятно, из-за смены стилистической окраски компонента-этнонима. ${ }^{4}$

Не всегда фиксация в словаре свидетельствует об употребительности фразеологизма. Так, приведенный выше компаративизм, судя по данным НКРЯ, не использовался литераторами XIX - начала XX веков. У классиков XIX века мы видим его формально-квантитативные варианты: «Так, братья, так: клянусь, я чист пред вами, / Как чистым был Христос пред палачами: / За грех других, как он, страдаю я...» (Сатин Н. М. «Теперь прости, семья родных мне братии...», 1835)*; «Я все узнал, я могу сказать тебе верно, что Элен невинна перед тобой, как Христос перед жидами» (Толстой Л. Н. Война и мир, 1867-1869)* - ср. с укр. невиний як Христос (ЛЕвченко 2007: 364); лемк. невиный як Христос (ВАРХОЛ-ІВченко 1990: 139). В русском языке на рубеже XX-XXI вв. последнее сравнение стало довольно активно употребляться: в наши дни оно встречается в сети Интернет (форумах, обсуждениях и т. д.) в лексических вариациях [кто] невинен (неповинен) [перед кем] как (аки) Христос перед жидами. Фразеологизм характеризует лиц мужского пола, имена которых вызывают общественно-политический резонанс, и в основном в однотипных конструкциях. ${ }^{5}$

\footnotetext{
${ }^{4}$ Прежде слово было разговорным наименованием еврея, поэтому у русских классиков (Пушкина, Бестужева-Марлинского, Гоголя, Достоевского, Куприна, Аксакова, Фета, Чехова и других) частотны сравнения типа богат как жид, скуп как жид, торговаться как жид, копить деньги как жид и т. п. Сейчас это считающееся дискриминирующим, грубо-просторечное, презрительное, бранное название лиц семитской языковой группы, поэтому лексема длительное время была табуирована во фразеографической практике.

${ }^{5}$ Например, «перед жертвами Большого террора 1937-1938 гг. тов. Сталин невинен, аки Христос переджидами?» (http://awas1952livejournal.com/1979784.html?thread=114650248); «Дерипаска здесь невинен, аки Христос перед жидами, как любит говорить один наш публицист» (http://regenta.livejournal.com/579050.html?thread=20753898); «Если Е. А. Чичваркин невинен,
} 
В народном сознании Иисус отождествляется с Творцом. Взаимозаменяемость лексем Бог и Христос (Иисус) демонстрируют прямые, но чаще косвенные фразеобиблеизмы: новг. как боженька в лапотках (босиком) прошёлся; как Исус Христос прошёл в лаптях по душе 'об ощущении легкости, приятности от выпитого’ (МокиЕнко-НикитинА 2008: 56, 237); укр. зрікся як апостол Петро Христа 'подло предал'; одказався як Петро від Бога 'трусливо предал’ (Юрченко-Івченко 1993: 9, 115); лемк. махати руков як Христос на Kарпаты (бог на Татры); махнати руками як бог над Чабинами; махнути руков як Ісус на Стропковы (ВАРХОЛ-ІВчЕнКо 1990: 116); слвц. та́vпит' rukou ako Kristus nad Slovenskom (SNK) - 'перестать обращать внимание, стать абсолютно равнодушным' ${ }^{6}$; рус. [жить (быть, находиться)] как у Христа (Бога) за пазухой (за пазушкой, в пазухе) (Мокиенко-Никитина 2008: 55, 726); укр. жити як у Христа (бога) за пазухою (Номис 1993: 111); бел. жыць як у Хрыста (бога) за пазухай (пазухаю) (ЛеПЕшАў 1993: 108) - 'о богатой, материально обеспеченной, беззаботной и привольной жизни' и т. п. Последнее сравнение в говорах восточных славян имеет многочисленные вариативные и синонимичные образования типа рус. [жить (быть, находиться)] как у Христа (Бога) за дверьми (дверями, дверью) (Мокиенко-НикитинА 2008: 55, 726); как у Христа (бога) за душой [жить (быть, находиться, чувствовать себя, отдыхать, почивать)] (ЛАвРов 1984: 110); укр. живе (жити) як у бога за дверима (дверми; за кроснами, під покришкою) (ЮрченкоІвчЕнКо 1993: 16) и пр., но только в русском языке появился его вариант [жить, чувствовать себя и т. п.] как у Христа под мылкой. ${ }^{7}$

как Христос перед жидами, можно рисовать с него икону, как это сделали убежденные в невиновности М. Б. Ходорковского» (http://m-yu-sokolov.livejournal.com/668178html); «Д. А. Медведев невинен, как Христос перед жидами» (http://m-yu-sokolov.livejournal.com/1008471.html). «Последний яркий пример - история с „Банком Москвы“ и его президентом Андреем Бородиным. Бывший зампред имел в виду, что Андрей Фридрихович невинен, как Христос перед жидами, а «вокруг нашего президента формируется будущий ГКЧП, члены которого активно работают против президента» (expert.ru/2011/04/8/felyeton-maksima-sokolova-8-aprelya); «они совсем уже несли на Никиту Сергеевича [Михалкова - И. К.] как на мертвого, то обличая его в сталинизме, в коем он был неповинен как Христос перед жидами, а то и вовсе вцепившись ему в стегна [устар. и диал. 'часть ноги от таза до коленного сгиба, бедро' - И. К.] за совершенно невинную фразу» (http://yarcenter.ru/content/view/30904/163); «С экзистенциальной грустью, свойственной всем, совершающим должностные преступления, он сообщает, что совершенно невинен как Христос перед жидами» (marbatova.ru/UltraBoard) и т. п.

${ }^{6}$ Устойчивые сравнения лемков и словаков представляют собой эксплицитный вариант известного многим языкам фразеологизма махнуть рукой [на кого, что] с той же семантикой.

${ }^{7}$ Сравнение вычленяется из текстов: «Блокада затянулась, даже слишком, / Но наш народ врагов своих разбил, / - И можно жить, как у Христа за пазухой, под мышкой, / Да только вот мешает бригадмил» (Высоцкий В. Я вырос в Ленинградскую блокаду..., 1961-1962); «Здесь за бронированными дверями мы как у Христа под мышкой» (Кожевников В. Щит и меч, 1968)*; «Ты, словно у Христа под мышкой, / Живешь несуетно и скромно. / Живи века, товарищ Мышкин. / Дыши легко, светло и ровно» (Соколов С. Товарищъ Мышкинъ [городу и человеку], 2003); «- А под солью будут лежать на мягких коврах, как у Христа под мылшкой, ясновельможный пан воевода на одном возу и ясновельможная пани - на другом» (Наживин И. Степан Разин. Казаки, 2009); «Восточно-Крымской экспедиции УРА! / Мы здесь живем как у Христа 
Христианская мифология связана с религиозной доктриной христианства и развивается во взаимодействии с ней, хотя часто отношения между ними противоречивы.

В сравнениях христиан евреи обычно предстают преследователями и мучителями Иисуса (= Бога): пол. męczyć go jak Żydzi Pana Jezusa; диал. mecys mie jak Zydzi Pana Boga 'очень сильно мучить'; oszukuje jak Żydzi Pana Jezusa (Pana Boga) 'обмануть' (NKP 3: 982, 983); слвц. osopil sa nan̆ ['обрушился на него'] ako židia na Krista Pána (ZÁtURECKÝ 2005: 164), но не всегда. Так, кашуб. gapic sę ['уставиться'] jak Żid w Póna Jezësa связывают с легендой о Вечном жиде (TREDER 1989: 156). Укр. жахаєичя (жахається) як жид Христа (Номис 1993: 218, Юрченко-Івченко 1993: 55) отражает лежащее на поверхности противопоставление приверженца иудаизма родоначальнику христианства и древние религиозно-мифологические представления славян: в условиях христианско-языческого двоеверия народная демонология приравнивала иноверцев к нечистой силе ${ }^{8}$ - ср. с бел. баіџца як чорт Хрыста (Фядосік 1979: 284).

Имя пророка из Галилеи обычно является компонентом устойчивых сравнений, имплицированных сюжетами Книги книг. Повествованиями о суде над главным новозаветным персонажем и его казни мотивированы компаративизмы: рус. paсnять [кого] как [Иисуса] Христа $;^{9}$ черногор. paсnеше га

под мышкой, / У всех есть в скалах свой чудесный уголок, / От дома мы отвыкли, но не слишком, / И быт палаточный по-своему не плох...» (Шильт Я. Гимн ВКАЭ, 2010); «Теперь я - как y Христа под мышкой. Квартира в пять комнат... Дача... Гараж... «Мерседес»... Участковый Тминов честь при встрече отдает. Все у меня в достатке. Остается одно: ЖИТЬ!» (Грущанский С. Счетовод, 2010).

${ }^{8}$ Ср. укр. бої сі гий жид свяченої води 'совсем не боится' (ЮрченКО-Івченко 1993: 55); лемк. бояти шя як жыд креста (ВАРХОЛ-ІВчЕНКО 1990: 55); пол. boi się jak Żyd chrztu (święconej wody) (NKP 3: 978); венг. fél, mint zsidó a kereszttől (ZÁTURECKÝ 2005: 409) - 'очень бояться’ и болг. бягам като евреин от кръст (КювлиЕВА 1986: 104); слвц. uteká od toho ako žid od kríža (ZÁTURECKÝ 2005: 385) с параллелями и вариантами устойчивых сравнений, образованных по структурно-семантическим моделям «бояться + как + черт атрибутов (служителей) христианства (Бога)» = 'очень бояться' и «бежать + как + черт [от] атрибутов христианства» = 'очень бояться и упорно избегать'.

${ }^{9}$ Фразеологизм вычленяется из текстов. Прямое значение 'пригвоздить к чему-л.; насильственно развести чьи-нибудь руки в разные стороны' реализуется в строках: «- Кто распял-то? -Жиды распяли, как Христа» (Краснов П. Н. От Двуглавого Орла к красному знамени, 1922)*; «Блатные распяли меня, как Иисуса Христа, на крестовине нар и заново разломали руку, обе кости (фраер не имеет права бить вора)» (Жжёнов Г. Прожитое, 2002)*; семантика 'предать каре, духовному наказанию' - в текстах: «С попами, с чудотворными иконами, с мощами - а... Распинает, как Христа! Понимаете, товарищ, силу сей аллегории» (Краснов П. Н. От Двуглавого Орла к красному знамени, 1922)*; «Если ты способен быть Буддой - воплощением помощи живым существам - будь готов к тому, что, когда ты начнешь проявлять эту способность, тебя распнут как Христа» (Клейн А. Дзен. // Пятое измерение, 12.2003. - http:// klein.zen.ru/pravda/001/dzen.html), а 'тянуть за руки в разные стороны' - в строках: «В цехе друзья зажимают руки Валеры в двух тисках, распинают его как пролетарского Христа» (Лебедев В. Вечный праздник в Москве. // Лебедь, 12.05.2003)*. Ср. также хорв. šireći ruke kao Isukrst; слвц. ruky má rozhodené ako Kristus na kríži (SNK). 
ка Жуђели [= 'евреи'] Христа ${ }^{10}$ (РАдовић 1962: № 4666); хорв. [tko] razapet je kao (ko) Isukrst (MENAC 2003-2004: 365); mučiti se kao Isukrst na raspelu ${ }^{11}$ (MATOŚ 1897: 17); mučiti se kak Isus na križu (MARESIĆ 1994: 96); mučiti se kak Kristuš [na križu] (MENAC 2011: 480) 'сильно мучиться, тяжело трудиться’; namučiti se kao Isukrst [na križu] (http://www.coolinarika.com/forum/coolinarika/.../ 58787) 'очень тяжело кому-л.; сильно мучается кто-л.'; napatiti se ko Isukrst na križu 'намучиться, настрадаться' (www.forum.hr/showthread.php?t=694280).

Троекратное отречение апостола Петра от своего Учителя отражено в фразеобиблеизме: рус. поступить [с кем] как Петр с Христом; ${ }^{12}$ отречься [от кого] как Петр от Христа (Мокиенко-НикитинА 2008: 496); укр. зрікся тричі як [апостол] Петро Христа; відрікатися / відректися як Петро [від] Христа [від кого] ${ }^{13}$; пол. jak Piotr Chrystusa zapart się (NKP 2: 935); слвц. zapriet' [niekogo] ako Peter Krista [zo strachu] (SNK); чеш. zapřit (prodat) [koho] jako Petr Krista (SČF 1983: 269, FoJTن 2013: 49). В словарях указывается его семантика: 'об отречении от старого друга, предательском отказе от признания дружеских отношений с кем-л. из корыстных побуждений, страха или трусости; совершить подлый поступок по отношению к ближнему' (МокиЕнкоНикитина 2008: 496). Однако слово отречься имеет также значение 'объявить кого-л. близкого чужим, отказаться от знакомства, связи и т. п. с близким' (без оттенков подло, предательски): рус. «Я все думаю о том, что Вы очень молоды и что я - у Вас - просто каприз. И если мама нажмет на Вас как следует - Вы отречетесь от меня, как Петр от Христа» (Вертинская Л. Синяя птица любви, 2004)*; укр. «Вступає в вік новий душа чиста. Замість лелії рожу цілують уста. А все ж, як Петро від Христа, відректися від Тебе не можу» (Тичина П. Мадонно моя..., 1920). В текстах возможна иная сочетаемость, при которой актуализируется семантика 'отказаться от своих устремлений, убеждений, веры и т. п.’: рус. «Правда, под атаками оппозиции Бухарин от своего лозунга обогащайтесь трижды отрекся, как Петр от Христа» (Устрялов Н. В. [Томский] Под знаком революции, 1927)*; «Ежели нет у вас веры да ежели отрекаться будете, как Петр от Христа, лучше

${ }^{10}$ Фразеологизм отражает распространенные в христианстве обвинения иудейского племени в деециде. Заметим, что при описании судебного процесса над пророком из Назарета Галилейского видно нарастание меры виновности евреев: в Евангелиях от Матфея и от Марка в выдаче Иисуса римлянам и требованиях распять его обвиняются лишь иудейские первосвященники и старейшины (Мф 27: 1, 12, 22-23; Мк 15: 1, 13-14); в Евангелии от Луки уже «весь народ стал кричать: смерть Ему! ... распни, распни Его!» (Лк 23: 18, 21), а в Евангелии от Иоанна утверждается, что именно иудеи увели и распяли Иисуса (Ин 19: 14-18).

${ }^{11}$ Обстоятельство места (на кресте, распятии) может отсутствовать: патис̌iti se (тис̌iti se) kao Isus (VIDOVIĆ 2006: 66, FINK-KovaČEVIĆ-HRNJAK 2010: 294).

12 «Это знаменитый Яков Иванович Ростовцев, ставший потом графом. У него, как оказалось, николаевского было только обложка, убеждений и нравственной стойкости у него вовсе не было, а потому один из первых николаевских слуг, который устыдился своего Монарха и благодетеля и поступил с ним как Петр со Христом во дворе Каиафы, был Ростовцев (Мещерский В. П. Мои воспоминания, 1897)*.

${ }^{13}$ «...я, трясця б мене напала, завійниця б мені визнулася в бокі, я його» [Мазепи - И. К.] відректися хотів, як Петро Христа (Липкий Б. Полтава, 1991). 
по домам расходитесь» (Гладков Ф. В. Повесть о детстве, 1948)*; укр. «Кандидат зрікся партійної своєї принадлежності як Петро від Христа» (14.08. 2009. - http://www.sq.com.ua/forum/showtread.php?t=35788page=10).

С библейской историей о предательстве Иудой за тридцать сребреников Христа связаны компаративизмы, лексические и квантитативные варианты которых уточняют семантику: рус. предать [кого] как Иуда [Христа]; хорв. izdati [koga] kao (ko) Juda Krista (MenaC 2003-2004: 366); izdati [koga] kao Juda Isusa [Krista]; чеш. zradit [jako] Jidáš Krista; tu zrádně bratřím učínil, jako Jidáš panu Kristovi (PAVLASOVÁ 2013: 83); слвц. zradit' [niekogo] ako Judáš Krista (SKLADANÁ 1999: 82) 'изменнически выдать кого-л., вероломно отдать во власть, распоряжение кого-л.; изменить, нарушить верность кому-л.' и рус. продать [кого] как Иуда [Христа]; бел. прадаў Хрыста нібы Юда (Кудласевич А. Пятро, грузи жыта!, 2010); хорв. prodati kao (ka) Juda Krista (Isusa) [za novac]; слвц. zradit' [niekogo] ako Judáš Krista [za 40 dinárov] (SNK) 'предать, изменить из корыстных побуждений'. Пол. całuje jak Judasz Christusa (NKP 1: 878) отражает способ предательства ${ }^{14}$; кашуб. kochac ['любить'] jak Judasz Christusa 'о лицемере' (NKP 1: 878) основано на «скрытой» антонимии. В хорватском языке частотен компаративизм odrekli se kao Juda Isusa.

К предсказаниям евангелистов о втором пришествии Иисуса Христа на землю перед концом света восходят фразеобиблеизмы с семантикой 'ждать долго, с надеждой на избавление, спасение от чего-л., с верой в лучшее или с нетерпением': рус. ждать (ожидать) [кого, реже что] как [евреи] Мессию (прихода Мессии); ${ }^{15}$ укр. ждати (чекати) як Месію (Месії, Iсуса Христа) [кого]; болг. очаквам / чакам като Мессия [някого]; хорв. čekati / očekuvati kao Mesiju [koga]; пол. czekać jak na Mesjasza [na kogoś] (Fink 2006: 238); czekać (wygladać [czego]) jak Żydzi Mesjasza (NKP 3: 979); слвц. čaka [ho] ako Żidia Mesiàša (ZÁtuRECKÝ 2005: 375, HABOVŠTIAKOVÁ-KROŠLÁKOVÁ 1996: 104); čakat' ako Mesiáša (na Mesiáša) [koho] (FINK 2006: 238); венг. vár vkit, mint a Messiást. С этим мотивом связан и фразеологизм явление Христа народу «1. книжсн., публ., возм. ирон. 'о появлении в обществе выдающейся личности, чьи идеи, труд и общественная деятельность направлены на служение людям и получают высокую оценку современников'; 2. разг., шутл. 'неожиданное, внезапное появление кого-л.'» (ДуБРовинА 2010: 708), ставший

14 «Предающий же Его дал им знак, сказав: кого я поцелую, тот и есть, возьмите Его и тотчас подошед к Иисусу, сказал: Радуйся, равви! И поцеловал Его» (Мф 26: 48-49).

${ }^{15}$ Сравнение вычленяется из текстов: «...ждали Павла на престол российский, как Мecсию...» (Долгоруков И. М. Повесть о рождении моем, происхождении и всей моей жизни, писанная мной самим и начатая в Москве, 1788-го года в августе месяце, на 25-ом году моей жизни. Ч. 4. 1791-1798)*; «И если стоустая молва донесет известия, что «новый» доступен и добр, то такого „доброго“ ждут в каждом уголке Сибири, как Мессию, повторяя с трогательным оптимизмом слова некрасовской Ненилы: „Вот приедет барин!“» (Станюкович К. М. В далекие края, 1886);* «...во всей России только народ-победитель, русские крестьяне, находится в состоянии рабства; они ждут своего освободителя, как евреи своего Мессию» (Давыдов Ю. Синие тюльпаны, 1988-1989)*; «Русская интеллигенция молилась на это собрание, ожидала его открытия как прихода Мессии...» (Волков О. В. Рождество в старом Петербурге, 1991)*. 
базой для сравнений: рус. [кто, что] как явление Христа народу; явиться как Христос народу; укр. явився як Христос народові (ДоБРольОжА 2003: 151) 'о неожиданном появлении кого-л., чего-л.' . ${ }^{16}$ Возможна дальнейшая фразеологическая деривация: «Жена смотрела на него, как на явление Христа народу. - Ты насовсем вернулся или как?» (Ильин А. Полонез для постояльца; цит. по: ДуьровинА 2010: 708); «Меня встретили как явление Христа народу ${ }^{17}$, но тут же чуть не бегом заставляют сдать в каптерку мою повидавшую виды голубую шубу, иначе я ее больше никогда не увижу» (Окуневская Т. Татьянин день, 1998)*.

Неинтернациональность ситуативных сравнений-библеизмов связана с принципом избирательности, «когда данная библейская ситуация отобразилась в виде фразеологической единицы в одном языке и не закрепилась в другом» (ГАК 1998: 732). Так, предсказание пророком из Галилеи разрушения Иерусалима отражено лишь в чеш. spláčeš nad tím jak Kristus pán nad Jeruzalémem 'лишиться чего-л., потерпеть неудачу, не добиться успеха; остаться c носOм' (ZAORÁLEK 2000: 472); мотив обличения им фарисеев, неоднократно встречающийся в Евангелиях от Матфея, Луки и Иоанна, запечатлен в хорв. bičevati $[k o g a]$ kao Isukrst Farizejce ${ }^{18}$, сцена суда над Иисусом - в венг. úgy érzi magát, mint Krisztus Pilátus elött ['чувствовать себя как Христос перед Пилатом'] 'очень плохо себя чувствовать' ${ }^{19}$. Чеш. kouká jako Jezule z jeslí 'смотрит невинно' (ZAORÁLEK 2000: 458) восходит к Евангелию от Луки, где говорится, что рожденного в хлеву (устроенному в пещере, по апокрифическому евангелию от Фомы) Иисуса положили в ясли; отчасти сравнение связано с традициями живописи и рождественских вертепов, открыток и т. д. в католичестве. Для православия изображения новорожденного Иисуса не типичны. Нет и специальных наименований для младенца Христа ${ }^{20}$ и, следовательно, фразеологизмов с ними, как, например, у чехов и немцев: vypadá jako

${ }^{16}$ См. тексты: «Сталин. Это было как явление Христа народу... Потом было много всяких восторгов и очевидцы показывали место у водокачки, где он прохаживался» (Давыдов В. Театр моей мечты, 2004)*; «Похороненный было Силаев явился на стоянку, к подсолнухам, среди бела дня нежданно, как Христос народу, в рубище вместо гимнастерки...» (Анфиногенов А. А внизу была земля, 1982)*; «Мне хотелось, чтобы слава упала с неба, явилась, как Христос народу, постучала в дверь, вошла и сказала: „Я - слава“» (Каверин В. А. Освещенные окна, 1974-1976)*.

${ }^{17}$ В данном случае мы видим контаминацию фразеологизма явление Христа народу и компаративизма встречать / встретить [кого] как [Иисуса] Христа 'радушно, надеясь на лучшее’: «Но вы их тоже натравили друг на друга, и такая началась среди них собачья свалка, что они сами же встретили Гитлера как Иисуса Христа» (Домбровский Ю. О. Факультет ненужных вещей, 1978)*.

${ }^{18}$ Встречается в текстах: «- A kako da ih ožigošemo? - pitaše Mavro. - Kako? Rušiti ih sa pijedestala njihove slave! Pokazati ih svijetu kakvi su, bičevati ih kao Isukrst one Farizejce!» (Kumičić E. Gospođa Sabina).

${ }^{19}$ Сравнение встречается в текстах: «- Most, önöknek arra a kérdésére, hogy miképp érzi magát. - Azt mondta, hogy úgy, mint Krisztus Pilátus előtt» (Mikszáth K. Fejedelmek találkozása).

${ }^{20}$ У католиков для Иисуса-младенца существует не одно имя: чеш. Jezule, Jezulátko, Ježíšek; нем. Jesuskind, Christkind.

Studia Slavica Hung. 60, 2015 
polské Jezulátko; dítě je jako Jezule (jak Jezulátko) (ZAORÁLEK 2000: 458); být krásný (roztomilý) jako jezulátko (PAVLASOVÁ 2013: 242); tváŕit se jako jezulátko; mít tváře jako jezulátko; být jako jezule; jako jezulátko; usmívat se ['улыбаться'] jako jezulátko (jezule); uculovat se ['улыбаться'] jako ježíšek (PAVLASOVÁ 2013: 160, 243-244); spát jako Jezulátko (FоJтŮ 2013: 49); нем. lächeln wie ein Christkind $^{21}$ (FoJтU 2013: 49) и т. п. На картинах Христос-младенец обычно изображается несколько наивным, милым, улыбающимся ребенком; фразеологизм mít tvář jako jezulátko имеет еще семантику 'иметь пухленькое, круглое, розовое лицо’ (PAVLASOVÁ 2013: 160-161).

В русском языке есть сравнения с именем Христа с уменьшительным суффиксом: перм. как Исусик [кто] 'об ухоженном': Как Исусик сидит - чистая, опрятная (СРГЮП 1: 389). Обычно он придает оборотам оттенок шутки или иронии: сидеть (стоять) как Исусик 'в расслабленной позе с блаженным, просветленным видом'; урал. разгоношить [кого] как Исусика 'раздеть кого-л. догола' (Мокиенко-НикитинА 2008: 237); глядеть (смотреть) как Иисусик 'притворяться невинным, ничего не понимающим' (БЕТЕХтинА 1999: 92). В результате часто отрицательная оценочность побеждает позитивные коннотации, вызываемые именем галилейского пророка: «- Пойде-ешь! Как Исусик, пойдешь у меня, ухажер сучий. Я те зароюсь... Снабженец отчаянно упирался, хрипло, всхлипами дышал...» (Шукшин В. Капроновая елочка, 1968)*; «Ничего не было, да? Глядит, как Исусик... Почему-то Сашка особенно оскорбился за этого „Исусика“” (Шукшин В. Обида, 1970-1972)*.

Чеш. tvárít se jako jezule соответствует русскому смотреть исусиком (MOKIENKO-WURM 2002: 212), прикидываться овечкой, блаженно ульббаться (PAVLASOVÁ 2013: 161). В кашуб. przińc jak taki jezusk слово jezusk тоже имеет значение 'святоша, лицемер, притворщик, ханжа'; оно, как и пол. uktadny ['вежливый, учтивый'] jak Jezusek восходит к изобразительному искусству (TREDER 1989: 104).

«Результатом воздействия иконографических, живописных традиций (в католичестве и скульптуре)» (КопосовА 2000: 35) являются вторичные, лишь отдаленно связанные с текстом Библии компаративизмы (ГАК 1998: 736): слвц. sedet'v strede ['сидеть в центре'] ako Kristus (Ježiš) (SNK) ${ }^{22}$; пол. wygladać jak Chrystos na krzyżu (FoJTUீ 2013: 49); нем. aussehen wie das Leiden Christi $^{23}$ (WALTER 2008: 189) 'выглядеть плохо, изможденным; иметь жалкий,

\footnotetext{
${ }^{21}$ Фразеологические аналоги в русском языке - устойчивые сравнения с компонентом ангело(че)к.

${ }^{22}$ В произведениях изобразительного искусства - например, на центральном панно алтаря работы Д. Баутса в церкви св. Петра в Лёвене «Тайная вечеря» (слвц. Posledná večera) Иисус Христос сидит в центре в кругу двенадцати апостолов при тайном обряде ставшего последним пасхального ужина, во время которого предсказывает, что один из учеников предаст его.

${ }^{23}$ Возникло в начале ХIX в. применительно к картинам, изображающим страдания Христа, и изображению деревянного распятия. Выражение das Leiden Christi 'страдания Христа' относится не только к Христовым мукам, но и к страдальческому выражению лица распятого (KÜPPER 1993: 492).
} 
болезненный или несчастный вид’. Древнейшая традиция портретирования Иисуса в готическом искусстве «бытует главным образом в народном творчестве, в вырезаемых из дерева грустных христосиках» (Косидовский 1990: 386), что мотивировало, вероятно, чеш. sedí jako zlámaný ['сломанный’] Ježíšek (ZAORÁLEK 2000: 458) 'сидит с печальным, унылым видом'. Нем. aussehen wie das Leiden Christi zu Pferde ['верхом на коне'] 'иметь достойный сожаления, плачевный, жалкий вид' и aussehen wie das Leiden Christi in Zivil ['в гражданском (платье)'] 'иметь болезненный (страдальческий) вид’ (WALTER 2008: 189) носят разговорный характер; первое возводят к изображению Христа во время процессии в праздник тела Христова или другого церковного шествия, второе же восходит, видимо, к речи солдат (KÜPPER 1993: 492).

Идиоэтничность некоторых фразеобиблеизмов можно связать с отличиями в вероисповедании. Так, у некоторых православных Пасха - центральный церковный праздник, посвященный воскресению Христа, - имеет перифрастические наименования, связанные с Иисусом: рус. [Светлое] Христово Воскресение, Христов день; серб. дан Христова ускрснућа, Ускрснуће Исусова и пр. Но эти названия встречаются только в русских сравнениях: ждать как Христова дня [кого, чего] (Огольцев 2001: 152); перм. ждать как Христов день (Христова дни) [кого, чего] (Мокиенко-НикитинА 2008: 164); ждать будто (пуще) [светлого] Христова Воскресения [чего] $]^{24}$ 'о нетерпеливом и радостном ожидании'; пск. покушать как в Христово воскресенье 'о вдоволь, сытно поевшем человеке'; перм. (шутл.) [появиться] как Христово яичко 'о человеке, которого давно ждали и который наконец появился' (МокиЕнкоНикитина 2008: 120, 775-776) и др.

Карел. [кинуть деньги кому] как Христа ради 'о брошенных кому-л. деньгах' (МокиЕнко-Никитина 2008: 726) возникло на базе выражения Христа ради - слов, с которыми нищие просили милостыню. Компаративизм с неодобрительной семантикой 'делать что-л. из милости; делать одолжение кому-л.' был употребителен в начале XIX века: «Эти гг. иноземные конторщики, которых мы величаем негоциантами, не выше почитают русских купцов, как своих артельщиков или биржевых дрягилей, и как будто ради Хриcma делятся с нами сотою частью своих барышей» (Булгарин Ф. В. Иван Иванович Выжигин, 1829)*; «Барыня бранится, в третий раз гоняет меня; я по целому дому бегала - нет как нет; а он вот еще тут прохлаждается, словно Христа ради воду носит нам, право!» (Даль В. И. Петербургский дворник, 1844)*.

Многие вторичные компаративизмы, маркированные именем центрального персонажа Библии, не имеют эквивалентов в других языках: сиб. как на Христе христом 'очень плохо' (ФЕдОРОв 1983: 214); хорв. vječni zaručnik ['жених, обрученный’] kao Isukrst; венг. fényes, mint a kis Jézuska bal szeme

\footnotetext{
${ }^{24}$ Ср. с текстами: «пуще светлого Христова воскресенья боя ждал» (Леонов Л. М. Вор, 1927)*; «,Скоро уходить“, - догадалась Эля, ей сделалось страшновато, хотя она и ждала этого дня, будто Христова воскресенья» (Астафьев В. Царь-рыба, 1974)*.

Studia Slavica Hung. 60, 2015
} 
['яркий как левый глаз молодого Иисуса']; úgy süt (ragyog), mint a Krisztus bal szeme ['горит (сверкает) как левый глаз Христа'] (O. NAGY 1976: 317, 395); megrázza, mint Krisztus (Jézus) a vargát ['трясти (кого-л.) как Христос (Иисус) сапожника'] (O. NAGY 1976: 317, 395; VöÖ 1999: 183); megfogja, mint Krisztus a vargát ['взять (кого-л.) как Христос сапожника'] (O. NAGY 1976: 395); többet szenvedett, mint Krisztus urunk ['страдал больше, чем наш Господь Христос'] (O. NAGY 1976: 395); felöltözik, mint Lakatosné Jézus neve napján ['одеться как Лакатошне в именины Иисуса'] 'одеться очень неряшливо'25 и т. д.

Первичные (прямые) и вторичные (косвенные) библеизмы отличаются способами возникновения и создания экспрессии, а тем самым и функционированием в языке. Прямые строят свою экспрессию на связи с Библией; опираются на ее авторитет, для большинства из них типично книжное употребление (которое часто развивается в направлении к ироничной оценке). Косвенные часто шутливы, нередко строят экспрессию на несовместимости значения или стилистической окраски с Библией, на противоречии библейским ценностям (Фойту 2013: 189-190) или употреблении имени персонажа в не свойственном ему контексте: рус. как Христос босиком прошёл (Скиталец [С. Г. Петров]. Огарки, 1906)*; словно Христос по душе босиком прошёлся; кубан. как Исус Христос на колеснице прокатился - 'об ощущении легкости, приятности от выпитого (чаще от алкоголя)'; как Исус - 1. 'о явившемся неожиданно рано, ранее предполагаемого срока человеке'; 2 . 'о человеке, пришедшем домой навеселе' - ср. с Ждали его как Бога, а он пришёл как Иисус; омск. как Исус Христос в лаптях проехал у кого, кому 'о саднящем у кого-л. (после похмелья) горле'; горьк., новг. как [будто] Христос [по душе (по сердиу)] в лапотках прошёлся; новг. как Христос босиком прошёлся; волог. как Христос [по сердиу] пройдет (МокиЕнко-Никитина 2008: 237, 726); рус. словно Христос по душе босиком прошелся (Родовой дом. // «Народное творчество», 16.02.2004)* - 'об ощущении приятности, благости от чего-л.'; «Возьми за лапки и разведи их в стороны. Как исусика» (Пелевин В. Generation «П», 1999)*; перм. как [с небес] Иисус Христос ноги обмыл 'о холодной, бодрящей воде' (СРГЮП 1: 380-381).

На стилистическую принадлежность и оттенок семантики фразеологизма влияет окрашенность слова в основании сравнения: ср. высокое, книжное возлюбить [кого] как Христа 'о возвышенной, праведной, чистой любви к кому-л.' (см. Мокиенко-НикитинА 2008: 726) и нейтральное полюбить как [кого] как Христа 'о чистой любви к кому-л.': «Напрасно чернила его клевета, / Он был безупречней, чем прежде, / И я полюбила его, как Христа...» (Некрасов Н. А. Русские женщины. Княгиня М. Н. Волконская, 1872)* - ср. с бел. Палюби мяне як Хрыста, / Што з нябёсаў сышоў на зямлю... / Палюби мяне як Хрыста, / Як Хрыстос я цябе палюблю (Тишко В. Палюби мяне як Хрыста, 2010).

\footnotetext{
${ }^{25}$ Информант - Й. А. Балажи.
} 
Как видим, популяризации некоторых фразеологических библеизмов иногда способствуют экстралингвистические факторы. Идиоэтничность части библейских компаративизмов объясняется разными причинами культурного плана, языковой игрой и некоторыми факторами иного порядка.

\section{Литература}

БЕТЕХТИНА 1999 = БЕТЕХТИНА Е. Н. Фразеологизмы с библейскими именами. СанктПетербург: «Издательство Санкт-Петербургского университета», 1999.

БИРИХ-МОКИЕНКО-СТЕПАНОВА 2005 = БИРИХ А. К., МОКИЕНКО В. М., СТЕПАНОВА Л. И. Русская фразеология. Историко-этимологический словарь. Москва: «АстрельАСТ-Люкс», 2005.

БоХЕНьСКИй 1993 = БОХЕньский Ю. Сто суеверий. Краткий философский словарь предрассудков. Москва: «Прогресс», 1993.

ВАРХОЛ-ІВЧЕНКО 1990 = ВАРХОЛ Н., ІВЧЕНКО А. Фразеологічний словник лемківських говірок Східної Словаччини. Братіслава: «Словацьке педагогічне видавництво», Пряшев: «Відділ української літератури», 1990.

ГАК 1998 = ГАК В. Г. Языковые преобразования. Москва: «Языки русской культуры», 1998.

ДоБРОЛЬОЖА 2003 = ДоБРОЛЬОЖА Г. Красне слово - як золотий ключ. Постіні народні порівняння в говірках Середнього Полісся та суміжних територій. Житомир: «Волинь», 2003.

ДуьРОВИнА $2010=$ ДуьРОВИнА К. Н. Энииклопедический словарь библейских фразеологизмов. Москва: «Флинта», «Наука», 2010.

ІвчЕнКО 1999 = ІвчЕнКо А. Біблійна фразеологія верхньолужсиикої мови. В кн.: Питання сорабістики. Львів: «Видавничий центр ЛНУ ім. І. Франка», 1999. 190-196.

КопосовА $2000=$ КоПосовА Н. Л. Библеизмы в русском и немецком языках. Ярославский педагогический вестник 2000/2: 31-35.

КосидОВский 1990 = Косидовский 3. Библейские сказания. Сказания евангелистов. Москва: «Политиздат», 1990.

КУЗНЕЦОВА 1995 = КУЗНЕЦОВА И. В. Устойчивые сравнения русского языка (в сопоставлении с украинскими и сербохорватскими). АКД. Санкт-Петербург, 1995.

КюВЛИЕВА 1986 = КюВлИЕВА-МишАЙКОВА В. Устойчивите сравнения в българския език. София: Издателство на българската академия на науките, 1986.

ЛАВРОВ 1984 = ЛАВРОВ Н. И. Смыссловая структура диалектной фразеологической единиџы (на материале новгородских и других русских говоров). АКД. Ленинград, 1984.

ЛЕВченко 2007 = ЛЕВченко О. П. Символи у фразеологічних системах украӥнської та російської мов. Лінгвокультурологічний аспект. АДД. Львів, 2007.

ЛЕПЕШАЎ 1993 = ЛЕПЕШАЎ І. Я. Фразеалагічны слойнік беларускай мовы. Т. 1. Мінск: «Беларуска энцыклапедыя», 1993.

МиХельСОН 1994 = МиХельСон М. И. Русская мысль и речь. Свое и чужое. Опыт русской фразеологии. Т. 1-2. Москва: «Терра», 1994.

МНМ = Мифы народов мира. Энциклопедия. Т. 1-2. Москва: «Советская энциклопедия», 1987-1988.

МоКИЕНКО-НикитинА 2008 = МокиЕНКо В. М., НикитинА Т. Г. Большой словарь русских народных сравнений. Москва: «ОЛМА Медиа Групп», 2008.

Studia Slavica Hung. 60, 2015 
НКРЯ = Наииональный корпус русского языка. http://www.ruscorpora.ru.

Номис 1993 = Украӥнські приказки, прислів'я і таке інше. Уклав М. Номис. [Передрук видання 1864 року з додатками.] Київ: «Либідь», 1993.

ОГОЛЬЦЕВ 2001 = ОГОЛЬЦЕВ В. М. Словарь устойчивых сравнений русского языка (синонимо-антонимический). Москва: «Русские словари-АСТ-Астрель», 2001.

РАдОВИЋ 1962 = РАдОВИЋ Ј. Збирка народних изрека. Титоград: Графички завод, 1962.

СРГЮП = Словарь русских говоров Южного Прикамья. Вып. 1. Пермь: «Пермский государственный педагогический университет», 2010.

ФЕДОРОВ 1983 = ФЕДОРОВ А. И. (ред.) Фразеологический словарь русских говоров Сибири. Новосибирск: «Наука», 1983.

Фойту 2013 = Фойту П. Динамика библейской фразеологии как причина сходств (отличий) во фразеологии разных языков (на материале немецко-чешского словаря библейской фразеологии). В кн.: Die slawische Phraseologie und die Bibel. Greifswald: «Ernst Moritz Arndt Universität Greifswald», 2013. 188-194.

Фядосік 1979 = ФядосІк А. С. (рэд.) Выслойі. Склад, сістэматызацыя тэкстаў, уступ, артыкул і камент. М. Я. Грынблата. Мінск: «Навука і тэхніка», 1979.

ЮРЧЕНКО-ІВЧЕНКО 1993 = ЮРЧЕНКО О. С., ІВЧЕНКО А. О. СЛовник стійких народних порівнянь. Харків: «Основа», 1993.

FINK 2006 = FINK ARSOVSKI Ž. Hrvatsko-slavenski rječnik poredbenih frazema. Zagreb: Knjegra, 2006.

FinK-KovaČEviĆ-HrnjaK 2010 = Fink Arsovski Ž., KovaČević B., HrnjaK A. Bibliografija hrvatske frazeologije i popis frazema analiziranih u znanstvenim i stručnim radovima. Zagreb: Knjegra, 2010.

FOJTU゚ 2013 = FOJTUீ P. Фразеологические интернационализмы в русском языке - Frazeologické internacionalizmy v ruštinè. Olomouc: Vyd. Univerzita Palackého, 2013.

HABOVŠTIAKOVÁ-KRoŠLÁKOVÁ 1996 = HABOVŠTIAKOVÁ K., KROŠLÁKOVÁ E. Frazeologický slovník. Človek a príroda vo frazeológii. Bratislava: Veda, 1996.

KÜPPER 1993 = KÜPPER H. Wörterbuch der deutschen Umgangssprache. Stuttgart-Dresden: Ernst Klett Verlag, 1993.

MARESIĆ 1994 = MARESIĆ J. Iz frazeologije govora Podravskih Sesveta. Fluminensia 6 (1994): 95-98.

MAtoś 1897 = MAtoś A. G. Odabrane pripovijetke. Zagreb, 1897. [CD-ROM.]

MENAC 2003-2004 = MENAC-MinALIĆ M. Hrvatski dijalektni frazemi s antroponimom kao sastavnicom. Folia onomastica Croatica 12-13 (2003-2004): 361-385.

MENAC 2011 = MENAC-Minalić M. Iz kajkavske frazeologije. Rasprave Instituta za hrvatski jezik i jezikoslovlje 37 (2011): 479-491.

MOKIENKO-WURM 2002 = MOKIENKO V., WURM A. Česko-ruský frazeologický slovník. Olomouc: Vyd. Univerzita Palackého, 2002.

NKP = KRZYŻANOWSKI J. (red.) Nowa księga przystów i wyrażeń przystowiowych polskich. T. 1-4. Warszawa: Państowy Institut Wydawniczy, 1969-1978.

O. NAGY 1976 = O. NAGY Gábor: Magyar szólások és közmondások. Budapest: Gondolat, 1976.

PAVLASOVÁ 2013 = PAVLASOVÁ M. Rusko-české frazeologizmy biblckého původu s křestními jmény v komparativním aspektu. Disertační práce. Brno, 2013.

SČF 1983 = Slovník české frazeologie a idiomatiky. Přirovnání. Praha: Academia, 1983.

SKLADANÁ 1999 = SKLADANÁ J. Slová z hlbín dávnych vekov. Bratislava: Grand Multitrade, 1999.

SNK = Slovenský národný korpus. http://korpus.sk. 
TREDER 1989 = TREDER J. Frazeologia kaszubska a wierzenia i zwyczaje (na tle porównawczym). Wejherowo: Muzeum Piśmiennictwa i Muzyki Kaszubsko-Pomorskiej, 1989.

VIDOVIĆ 2006 = VIDOVIĆ Bolt I. Poteškoće u prevođenju frazema (na primjerima hrvatskih i poljskih frazema) Strani jezici 35. Zagreb, 2006. 63-70.

VöÖ 1999 = VöÖ Gabriella: Szaván fogjuk. Erdélyi magyar szólások. Székelyudvarhely: Erdélyi Gondolat, 1999.

WALTER 2008 = WALTER H. Wörterbuch deutscher sprichwörtlicher und phraseologischer Vergleiche. Teil 1. Hamburg: Dr. Kovač, 2008.

ZAORÁLEK 2000 = Lidová rčení. Zpracoval Jaroslav Zaorálek. Praha: Academia, 2000.

ZÁTURECKÝ 2005 = ZÁTURECKÝ A. Slovenské príslovia, porekadlá, úslovia a hádanky. Bratislava: Slovenský Tatran, 2005. 